\title{
A Morphometrical Study on the Skull of Goat (Capra hircus) in Mizoram
}

\author{
Estudio Morfométrico del Cráneo de Cabra (Capra hircus) en Mizoram
}

\author{
O. P. Choudhary ${ }^{1}$; Priyanka $^{2}$; P. C. Kalita ${ }^{1}$; R. S. Arya ${ }^{3}$; A. Kalita ${ }^{1}$; P. J. Doley ${ }^{1}$ \& Keneisenuo ${ }^{1}$
}

CHOUDHARY, O. P.; PRIYANKA; KALITA, P. C.; ARYA, R. S.; KALITA, A.; DOLEY, P. J. \& KENEISENUO. A morphometrical study on the skull of goat (Capra hircus) in Mizoram. Int. J. Morphol., 38(5):1473-1478, 2020.

SUMMARY: The present study was designed to elaborate on the morphometry of the skull of non-descript goats in Mizoram state of India. The study was conducted on the skull of twelve $(n=12)$ adult goats of either sex ( $n=6$ males and $n=6$ females) collected from the local slaughterhouses. Altogether, forty-one different measurements were taken morphologically. In the present study, the cranial and facial bones were the major components of the skull with a total of thirty-two bones. There were three single and four paired cranial bones with a total of eleven bones. There were one single and the rest were paired facial bones with a total of twenty-one bones. The cranial bones were occipital, parietal, interparietal, sphenoid, ethmoid, frontal and temporal. The facial bones were maxilla, premaxilla (incisive), palatine, pterygoid, nasal, lacrimal, zygomatic (malar), vomer, turbinate, mandible and hyoid. The skull measurements showed that the skull of the goat was elongated and dolichocephalic as per the cephalic index (47.82 \pm 0.05 ). The length and width of the skull was $19.28 \pm 0.03 \mathrm{~cm}$ and $9.22 \pm 0.04 \mathrm{~cm}$, respectively. There were two supraorbital foramina on both sides of the frontal bone. The prominent facial tuberosity lies dorsally to the third superior premolar tooth. Single infraorbital foramen was located dorsally to the junction of the first and second superior premolar teeth on maxilla bone. The orbits were round and complete and situated on a frontolateral oblique plane. It can be concluded that the findings of this study would assist the comparative studies with other domesticated animals in the future and would be applicable in clinical veterinary practice and even in zooarchaeology.

KEY WORDs: Goat; Skull; Morphometrical, index; Cranial; Facial.

\section{INTRODUCTION}

The head phenotypic appearance of the animal species depends strongly on the shape of the skull (Kunzel et al., 2003). Several studies on the skull bones morphometrics have been undertaken in many domestic species such as the dog (McGreevy et al., 2004), cat (Kunzel et al.), goat (Olopade \& Onwuka, 2004, 2009a,b; Choudhary et al., 2019a), horse (Evans \& McGreevy, 2006), sheep (Olopade \& Onwuka, 2007; Pare's et al., 2010) and Iranian cattle and dromedary camel (Monfared, 2013a; Monfared, 2013b; Choudhary et al., 2016) in an attempt to give baseline anatomical information. The skull has also been used as a major skeletal structure to determine taxonomic affiliations as it is subject to phenotypic changes because of selective breeding (Bruenner et al., 2002).

There is the paucity of the literature on the morphometry of the skull of non-descript goat in Mizoram; thus, the present study aimed to investigate morphometrical parameters of the skull of goat in Mizoram, thereby contributing in filling the gap of knowledge in the field of gross and forensic anatomy.

\section{MATERIAL AND METHOD}

The study was conducted on the skull of twelve $(\mathrm{n}=$ 12) adult non-descript goats (aged about 9-10 months) of either sex ( $\mathrm{n}=6$ males and $\mathrm{n}=6$ females) without any skeleton disorder. The head of non-descript goats was collected from the local slaughterhouses located in the Bawngkawn, Aizawl, Mizoram, from July to December 2019. All the procedures involving sample collection were conducted as per the Institutional Animal Ethics Committee (IAEC) which is under Committee for the Purpose of Control and Supervision of Experiments on Animals (CPCSEA), Ministry of Environment, Forest and Climate Change, Government of India for the College of Veterinary Sciences and Animal Husbandry, Selesih, Aizawl, Mizoram.

\footnotetext{
${ }^{1}$ Department of Veterinary Anatomy and Histology, College of Veterinary Sciences and Animal Husbandry, Central Agricultural University (I), Selesih, Aizawl, Mizoram, India. ${ }^{2}$ Department of Veterinary Microbiology, College of Veterinary Sciences and Animal Husbandry, Central Agricultural University (I), Jalukie, Peren, Nagaland, India.

${ }^{3}$ Department of Veterinary Pathology, College of Veterinary Sciences and Animal Husbandry, Central Agricultural University (I), Selesih, Aizawl, Mizoram, India.
} 
The collected specimens were macerated by the boiling maceration technique for skeletal preparation (Choudhary et al., 2013a,b; Choudhary et al., 2015). The macerated skull samples were kept in 4\% hydrogen peroxide for one day to make the bones whitish and utilize for gross anatomical studies. Altogether a total of forty-one measurements were taken in the skull of the non-descript goat by using digital vernier caliper (Resolution $0.01 \mathrm{~mm}$ or 0.0005 inches: Accuracy $+/-0.03 \mathrm{~mm}$ ). All the measurements obtained were analyzed by routine statistical analysis (Snedecor \& Cochran, 1994) and the results obtained were expressed as mean \pm standard deviation (S.D.). The parameters taken in the skull of the non-descript goat are delineated below and revealed in figures $1-4$.

1. Skull parameters (Figs. 1 and 2)

a) Length (SKL): Distance between the highest points of the parietal bones to the middle of the rostral margin of the incisive bone.

b) Width (SKW): Distance between two zygomatic arches.

c) Skull/cephalic index (SKI): Skull width X 100/skull length.

d) Skull base length (SKBL): Distance between the dorsal margin midpoints of the foramen magnum to the middle point of the cranial margin of the incisive bone.

2. Cranial parameters (Fig. 1)

a) Cranial length (CRL): Distance from the central point of the frontonasal suture to the middle point of the nuchal crest.

b) Cranial width (CRW): Distance between the bases of both the horns.

c) Cranial index (CRI): Cranial width X 100/ cranial length.

d) Cranial height (CRH): Distance between the central points of the dorsal rim of the foramen magnum to the point of the origin of the interfrontal suture.

e) Capacity of the cranial cavity (CRC): The cranial cavity was filled with mustard grains through the foramen magnum up to its brim after plugging the all foramina of the cranial cavity by the help of cotton. The mustard grains were filled into a measuring cylinder to get the volume in $\mathrm{cm}^{3}$.

3. Facial parameters (Fig. 1)

a) Facial length (FAL): Distance from the frontonasal suture to the center of the incisive bone.

b) Facial width (FAW): Distance between the caudal extents of the orbital rims.

c) Facial index (FAI): Facial width X 100/ facial length.

4. Maxilla parameters (Fig. 3)

a) Length of the maxilla (MAL): Distance from parietofrontal suture to the frontonasal suture.

b) Width of the maxilla (MAW): Distance from interfrontal suture to the rim of the orbit.

c) Infraorbital foramen distance (IOFD): Distance between two infraorbital foramina.

d) Facial tuberosity to the infraorbital foramen (FTIO): It was measured from the level of most lateral bulging of facial tuberosity to mid-level of the infraorbital foramen.

e) Infraorbital foramen to root of the alveolar tooth (IOSP): It was measured from the mid-level of the infraorbital foramen to the alveolar root of the superior second premolar tooth.

5. Premaxilla parameters (Fig. 3)

a) Length of the premaxilla (PML): Maximum length of the premaxilla.

b) Width of the premaxilla (PMW): Maximum width of the premaxilla.

6. Lacrimal parameters (Fig. 3)

a) Length of lacrimal (LAL): Distance from the frontolacrimal suture to the junction between the lacrimal and maxilla bones.

b) Width of lacrimal (LAW): Distance from the frontolacrimal suture to the

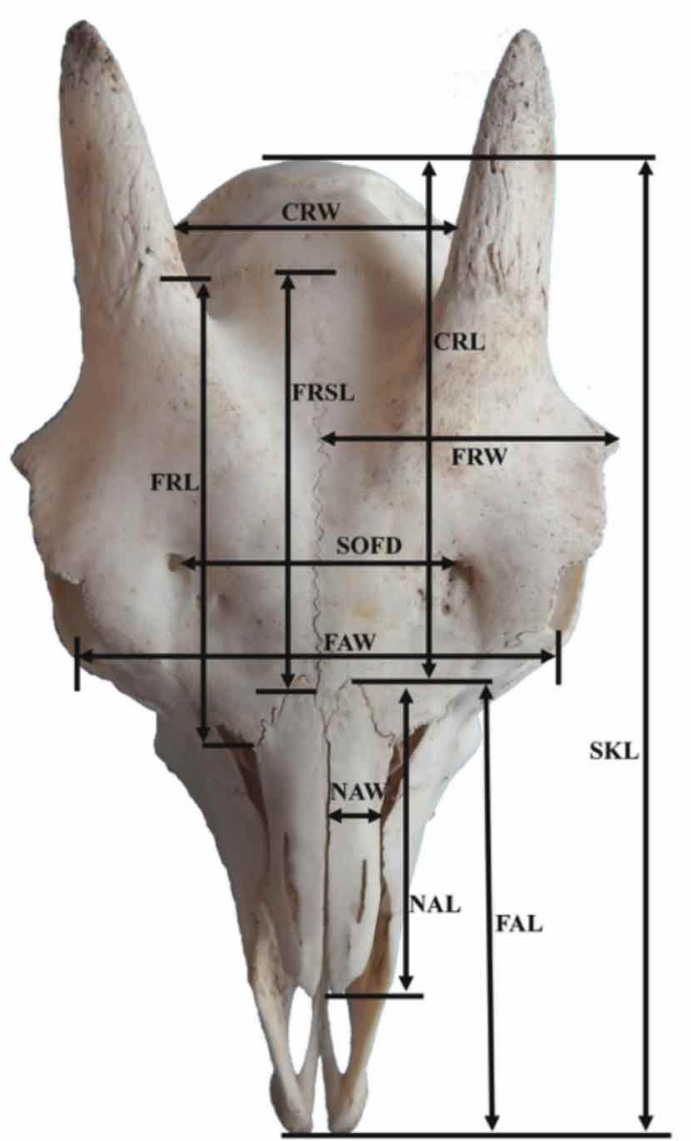

Fig. 1. Measurements of the skull (dorsal view) of goat showing cranial length (CRL), cranial width (CRW), facial length (FAL), facial width (FAL), length of skull (SKL), width of skull (SKW), length of frontal (FRL), width of frontal (FRW), length of frontal suture (FRSL), length of nasal (NAL) and width of nasal bone (NAW).

junction between the lacrimal and malar bones.

7. Nasal parameters (Fig. 1)

a) Length of nasal bone (NAL): Distance from the central point of the frontonasal suture to the rostral end of the internasal suture.

b) Width across nasal bone (NAW): Distance across the nasal bones or distance between the naso-maxillary sutures.

c) Nasal Index (NI): Nasal width X 100/ nasal length.

8. Palatine parameters (Fig. 2)

a) Length of palatine (PAL): Distance between the rostral mid sutured line of incisive bone and the caudal nasal spine of the palatine bone.

b) Width of palatine (PAW): Distance at the horizontal plate of palatine bone behind the last molar tooth.

9. Occipital parameters (Fig. 4)

a) Length of occipital (OCL): Distance between external margins of two paracondylar processes

b)Height of occipital $(\mathrm{OCH})$ : Distance from base of the occipital condyle to the starting point of the sagittal crest. 


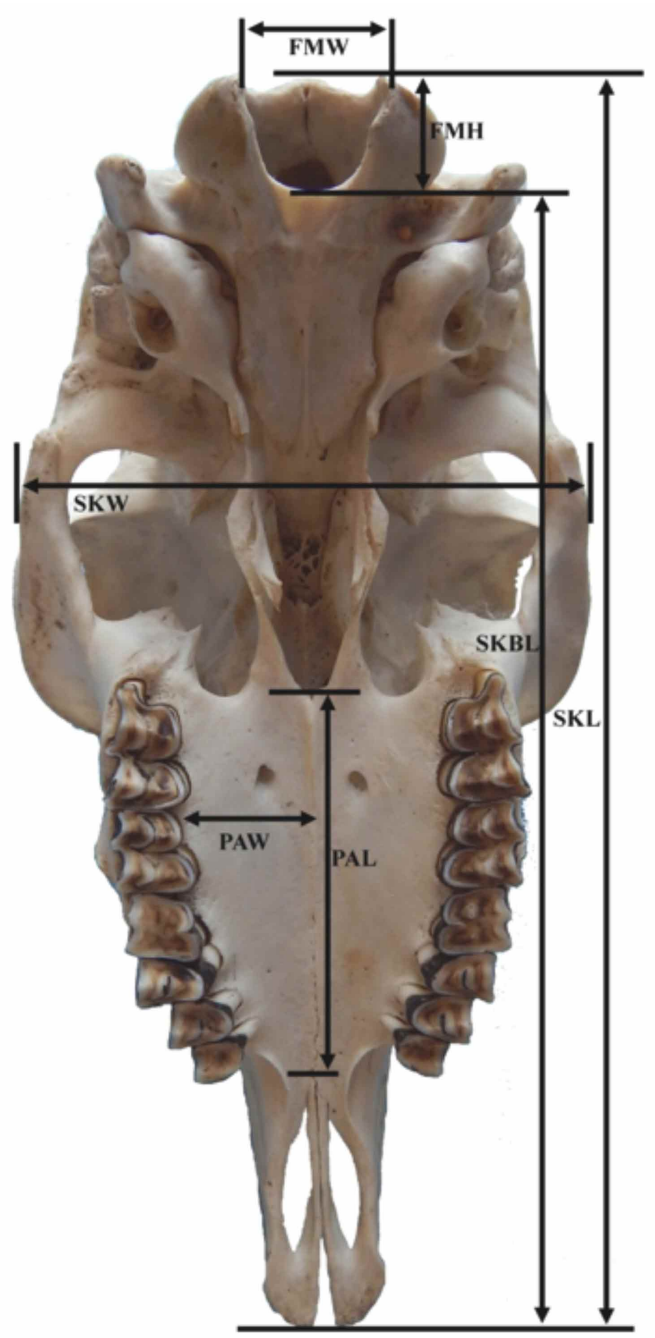

Fig. 2. Measurements of the skull (ventral view) of goat showing width of the foramen magnum (FMW), height of foramen magnum (FMH), length of skull (SKL), skull base length (SKBL), width of skull (SKW), length of palatine (PAL) and width of palatine (PAW). c) Intercondylar width (ICW): Width between the lateral margins of the occipital condyles.

d) Interparacondylar width (IPCW): The greatest width between the ventromedial end of the paracondylar processes.

e) Height of foramen magnum (FMH): Distance between the midpoints of the dorsal and ventral rims of the foramen magnum.

f) Width of the foramen magnum (FMW): Distance between the two occipital condyles.

g) Foramen magnum index (FMI): Foramen magnum height X 100/ foramen magnum width.

h) Area of the foramen (FMA): It was calculated by using the formula- $\approx X 22 / 7 \mathrm{X}$ $\mathrm{WH}$, where $\mathrm{W}$ and $\mathrm{H}$ were the width and height of the foramen magnum.

i) Circumference of foramen magnum (FMC): Length of the entire rim of the foramen magnum measured by the thread.

10. Parietal parameters (Fig. 4):

a) Height of parietal (PRH): Maximum height of parietal bone.

b) Width of parietal (PRW): Maximum width of parietal bone.

11. Frontal parameters (Fig. 1):

a) Length of frontal (FRL): Length between the parietofrontal suture and frontonasal suture.

b) Width of frontal (FRW): Distance between the interfrontal suture and dorsocaudal margin of the orbit.

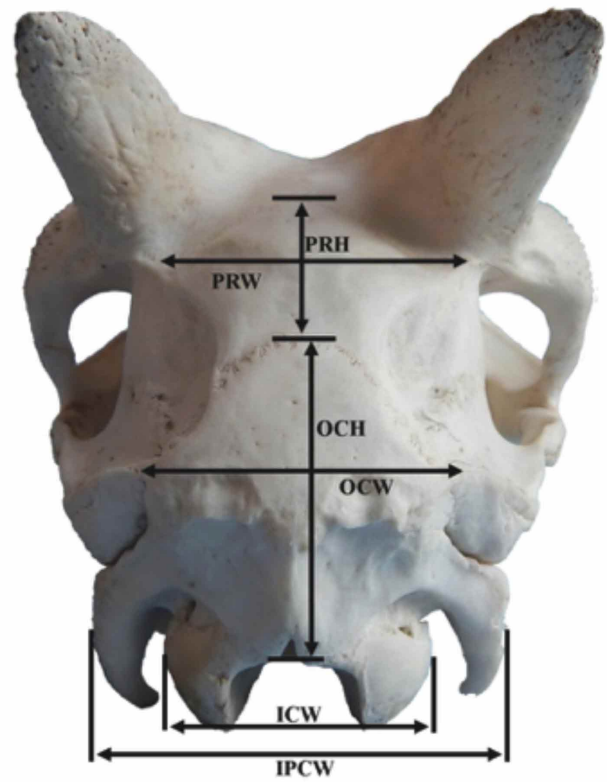

Fig. 4. Measurements of the skull (nuchal view) of goat showing height of parietal (PRH), width of parietal (PRW), height of occipital $(\mathrm{OCH})$, width of occipital (OCW), intercondylar width (ICW) and interparacondylar width (IPCW).

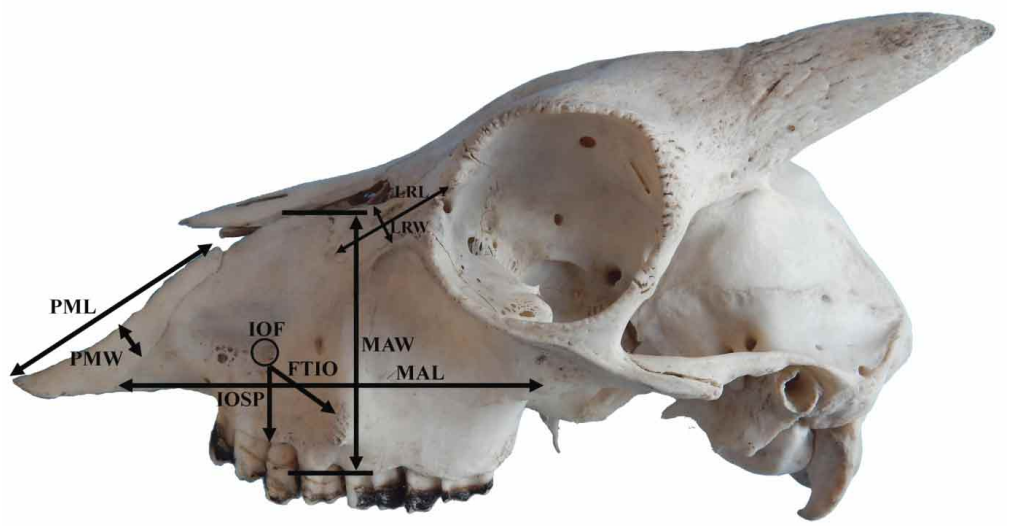

Fig. 3. Measurements of the skull (lateral view) of goat showing length of premaxilla (PML), width of premaxilla (PMW), length of maxilla (MAL), width of maxilla (MAW), length of lacrimal (LAL), width of lacrimal (LAW), distance between the most lateral bulging of the facial tuberosity to the infraorbital foramen (IOFT) and distance from infraorbital foramen to root of the second superior premolar tooth (IOSP). 
CHOUdHARY, O. P.; PRIYANKA; KALITA, P. C.; ARYA, R. S.; KALITA, A.; DOLEY, P. J. \& KENEISENUO. A morphometrical study on the skull of goat (Capra hircus) in Mizoram. Int. J. Morphol., 38(5):1473-1478, 2020.

c) Length of frontal suture (FRSL): Length between parietofrontal suture and frontonasal suture.

d) Supraorbital foramen distance (SOFD): Distance between the two supraorbital foramen.

\section{RESULTS AND DISCUSSION}

The cranial and facial bones were the major components of the skull with a total of thirty-two bones. There were three single and four paired cranial bones with a total of eleven bones. There were one single and the rest were paired facial bones with a total of twenty-one bones. The cranial bones were occipital, parietal, interparietal, sphenoid, ethmoid, frontal and temporal. The facial bones were maxilla, premaxilla (incisive), palatine, pterygoid, nasal, lacrimal, zygomatic (malar), vomer, turbinate, mandible and hyoid as reported in ox (Raghavan, 1964), dog (Miller et al., 1964), ruminants (Sisson, 1964), horse (Getty, 1975), chital (Kumawat et al., 2014) and blackbuck (Choudhary \& Singh, 2016).

The skull measurements showed that the skull of the goat was elongated and dolichocephalic as per the cephalic index as reported in kagani goat (Sarma, 2006) and chital (Kumawat et al.), blackbuck (Choudhary et al., 2015) and Zovawk pig (Choudhary et al., 2019a). In contrast, the skull was mesaticephalic in dog (Miller et al.), brachycephalic in tiger (Joshi, 2004) and mesocephalic in Malayan sun bear (Kalita et al., 2019). The skull index was $47.82 \pm 0.05$ in the present study, whereas the same measurement was 53.57 $\mathrm{cm}$ in Mehraban sheep (Karimi et al., 2011), 38.23 \pm 0.85 in donkey (Zhu et al., 2014), 47.77 \pm 1.96 in Markhoz goat (Goodarzi \& Hoseini, 2014), 46.12 $\pm 0.12 \mathrm{~cm}$ in blackbuck (Choudhary \& Singh, 2015b), $46.51 \pm 0.29 \mathrm{~cm}$ in dromedary camel (Choudhary et al., 2016), 70.56 \pm 0.22 in wild pig (Choudhary et al., 2017), 53.56 \pm 0.11 in Zovawk pigs (Choudhary et al., 2019b) and 80.48 in Malayan Sun bear (Kalita et al.).

The length, width of the skull were $19.28 \pm 0.03 \mathrm{~cm}$, $9.22 \pm 0.04 \mathrm{~cm}$, respectively, whereas the length, width of the skull was $44.30 \pm 5.35 \mathrm{~cm}, 16.90 \pm 1.76$ in donkey (Zhu et al.), $18.67 \pm 0.66 \mathrm{~cm}, 8.91 \pm 0.18 \mathrm{~cm}$ in Markhoz goat (Goodarzi \& Hoseini) and $20.68 \pm 0.02 \mathrm{~cm}, 9.54 \pm 0.03 \mathrm{~cm}$, respectively in blackbuck (Choudhary \& Singh, 2015b). The cranial length, width, height in the present study were $9.10 \pm 0.03 \mathrm{~cm}, 7.02 \pm 0.01 \mathrm{~cm}, 7.65 \pm 0.02 \mathrm{~cm}$, respectively, whereas the same parameters were $10.40 \pm 0.02 \mathrm{~cm}$, $6.13 \pm 0.02 \mathrm{~cm}, 7.13 \pm 0.02 \mathrm{~cm}$, respectively in blackbuck (Choudhary \& Singh, 2015b). The cranial index was $77.14 \pm 0.05$ in the present study; however, the cranial index was $52.76 \pm 1.13$ in Mehraban sheep (Karimi et al.),
$54.04 \pm 2.29$ in Markhoz goat (Goodarzi \& Hoseini) and $59.00 \pm 0.11$ in blackbuck (Choudhary \& Singh, 2015b).

The facial length and width was $10.20 \pm 0.08 \mathrm{~cm}$ and $6.58 \pm 0.02 \mathrm{~cm}$ respectively, whereas the same parameters were $11.53 \pm 0.08 \mathrm{~cm}, 9.30 \pm 0.015 \mathrm{~cm}$ respectively in blackbuck (Choudhary \& Singh, 2015b); The facial index in the present study was $85.44 \pm 1.89$, whereas the facial index was $85.44 \pm 1.89$ in Mehraban sheep (Karimi et al.), $138.48 \pm 0.57$ in Kagani goat (Sarma), $100.77 \pm 6.85$ in Markhoz goat (Goodarzi \& Hoseini) and $80.67 \pm 0.44$ in blackbuck (Choudhary \& Singh, 2015b). The skull base length was $18.18 \pm 0.06 \mathrm{~cm}$ in the present study; however, in blackbuck, the skull base length was $18.31 \pm 0.02 \mathrm{~cm}$ (Choudhary \& Singh, 2015b).

The cranial cavity was oval and elongated caudally, situated on the dorsal aspect of the nasal sinus as reported in the blackbuck (Choudhary \& Singh, 2016). The capacity of the cranial cavity was $103.44 \pm 0.71 \mathrm{~cm}^{3}$ in the present study, while the same parameter was $113 \pm 0.84 \mathrm{~cm}^{3}$ in Kagani goat (Sarma), $130.86 \pm 11.55 \mathrm{~cm} 3$ in Mehraban sheep (Karimi et al.) and $107.83 \pm 0.86 \mathrm{~cm}^{3}$ in blackbuck (Choudhary \& Singh, 2015b).

The occipital bone height and width in the present study was $3.78 \pm 0.01 \mathrm{~cm}$ and $3.92 \pm 0.02 \mathrm{~cm}$, respectively, whereas the same parameter was reported as $5.21 \pm 0.01 \mathrm{~cm}$ and $5.76 \pm 0.00 \mathrm{~cm}$ in blackbuck (Choudhary \& Singh, $2015 b)$. The intercondylar and interparacondylar width was $3.70 \pm 0.01 \mathrm{~cm}$ and $4.67 \pm 0.01 \mathrm{~cm}$, respectively; however, the same parameters were $4.62 \pm 0.01 \mathrm{~cm}$ and $5.29 \pm 0.01 \mathrm{~cm}$, respectively in blackbuck (Choudhary \& Singh, 2015b).

The foramen magnum was large and oval as reported in ox (Raghavan), chital (Ramswarup, 2011) and blackbuck (Choudhary \& Singh, 2016), however, the foramen magnum was almost a circular opening in horse (Getty). The height, width, circumference, area of the foramen magnum in the present study were $1.81 \pm 0.02 \mathrm{~cm}, 1.71 \pm 0.01 \mathrm{~cm}, 5.73 \pm 0.01$ $\mathrm{cm}$ and $2.43 \pm 0.06 \mathrm{~cm} 2$, respectively; however same parameters were reported as $1.74 \pm 0.00 \mathrm{~cm}, 2.03 \pm 0.00 \mathrm{~cm}$, $8.22 \pm 0.01 \mathrm{~cm}, 0.88 \pm 0.00 \mathrm{~cm}^{2}$, respectively in blackbuck (Choudhary \& Singh, 2015b). Sarma also mentioned height, width, circumference, area of the foramen magnum as $3.08 \pm 0.35 \mathrm{~cm}, 3.12 \pm 0.36 \mathrm{~cm}, 12.30 \pm 0.28 \mathrm{~cm}, 2.53 \pm 0.58 \mathrm{~cm}^{2}$, respectively in Kagani goat. The foramen index in the present study was $94.47 \pm 0.28$, which was $89.32 \pm 14$. 1 in Markhoz goat (Goodarzi \& Hoseini) and $98.71 \pm 0.28$ in blackbuck (Choudhary \& Singh, 2015b).

The length, width of the frontal bone was $6.78 \pm 0.03$ $\mathrm{cm}, 8.90 \pm 0.01 \mathrm{~cm}$, respectively in the present study, whereas 
the same parameter was $7.75 \pm 0.01 \mathrm{~cm}, 4.81 \pm 0.00 \mathrm{~cm}$ in blackbuck (Choudhary \& Singh, 2015b). The length of the interfrontal suture was $6.74 \pm 0.01 \mathrm{~cm}$, which was $5.46 \pm 0.008$ $\mathrm{cm}$ in blackbuck (Choudhary \& Singh, 2015b). The length and width of the maxilla was $8.87 \pm 0.04 \mathrm{~cm}$ and $4.84 \pm 0.01$ $\mathrm{cm}$, respectively, whereas it was $9.29 \pm 0.005 \mathrm{~cm}$ and $4.83 \pm 0.008 \mathrm{~cm}$ in blackbuck (Choudhary \& Singh, 2015b).

In the present study, the facial tuberosity of goat was located above the third superior premolar tooth which has also been reported in ox (Ghosh, 2012), chital (Kumawat et al.) and blackbuck (Choudhary \& Singh, 2015a). However, the facial tuberosity of the Madras Red sheep was prominent and placed at the level of fifth cheek tooth (Sundaram et al., 2019). Single infraorbital foramen was located dorsally to the junction of the first and second superior premolar teeth on maxilla bone.

The distance between the most lateral bulging of the facial tuberosity to the infraorbital foramen and from latter to the root of the alveolar tooth directly ventral to it was $2.25 \pm 0.03 \mathrm{~cm}, 1.44 \pm 0.04 \mathrm{~cm}$, respectively; while the same parameters were 1.6-1.8 cm, $1.3-1.6 \mathrm{~cm}$ in West African dwarfs goats (Olopade \& Onwuka, 2005); $1.85 \pm 0.14 \mathrm{~cm}$, $1.75 \pm 0.19 \mathrm{~cm}$ in black Bengal goat (Uddin et al., 2009); $2.06 \pm 0.14 \mathrm{~cm}, 1.13 \pm 0.11 \mathrm{~cm}$ in Gwembe Valley dwarf goat were (Kataba et al., 2014); $2.8 \mathrm{~cm}, 2.5 \mathrm{~cm}$ in Iranian native cattle (Monfared, 2013a) and 2.37 $\pm 0.00 \mathrm{~cm}, 0.72 \pm 0.01 \mathrm{~cm}$ in blackbuck (Choudhary \& Singh, 2015a). The infraorbital nerve block can be achieved extraorally by injecting anesthetic drugs approximately $1.4-1.5 \mathrm{~cm}$ above the root of the second superior premolar tooth in the infraorbital foramen. The infraorbital nerve block is used in the surgical interventions related to the upper lip, nose and skin supplied by the infraorbital nerve.

The premaxilla length and width in the present study were $5.85 \pm 0.03 \mathrm{~cm}$ and $0.96 \pm 0.02 \mathrm{~cm}$, respectively, while it was $7.23 \pm 0.00 \mathrm{~cm}$ and $1.00 \pm 0.00 \mathrm{~cm}$, respectively in blackbuck (Choudhary \& Singh, 2015b). The length and width of the palatine bone was $6.01 \pm 0.04 \mathrm{~cm}$ and $4.73 \pm 0.03$ $\mathrm{cm}$, respectively, whereas it was $6.04 \pm 0.04 \mathrm{~cm}$ and $3.23 \pm 0.02$ $\mathrm{cm}$, respectively in blackbuck (Choudhary \& Singh, 2015a).

In the present study, the nasal bone length and width were found to be $5.59 \pm 0.03 \mathrm{~cm}$ and $0.97 \pm 0.01 \mathrm{~cm}$, respectively; whereas the same parameters were $6.50 \pm 0.11$ $\mathrm{cm}$ and $3.20 \pm 0.57 \mathrm{~cm}$ in Kagani goat (Sarma) and 5.69 \pm 0.01 $\mathrm{cm}$ and $1.29 \pm 0.01 \mathrm{~cm}$ in blackbuck (Choudhary \& Singh, 2015b). The lacrimal bone length and width in the present study was $3.57 \pm 0.02 \mathrm{~cm}$ and $1.18 \pm 0.02 \mathrm{~cm}$, respectively, whereas it was $4.36 \pm 0.01 \mathrm{~cm}$ and $1.71 \pm 0.01 \mathrm{~cm}$, respectively in blackbuck (Choudhary \& Singh, 2015b).

\section{CONCLUSIONS}

These morphometric databases provided in the present study on the skull of goat can be an asset for further research in the field of morphological and applied anatomy on the domesticated and wild animals. It can be concluded that the findings of this study would assist the comparative studies with other domesticated animals in future and would be applicable in clinical veterinary practice and even in zooarchaeology.

ACKNOWLEDGMENTS. The authors are grateful to the Dean, College of Veterinary Sciences and Animal Husbandry, Central Agricultural University (I), Aizawl, Mizoram for providing all the necessary facilities to carry out present research investigation.

CHOUDHARY, O. P.; PRIYANKA, KALITA, P. C.; ARYA, R. S.; KALITA, A.; DOLEY, P. J \& KENEISENUO. A Estudio morfométrico del cráneo de cabra (Capra hircus) en Mizoram. Int. J. Morphol., 38(5):1473-1478, 2020.

RESUMEN: El estudio fue diseñado para elaborar la morfometría del cráneo de cabras no definidas en Mizoram. El estudio se realizó en el cráneo de 12 cabras adultas 6 machos y 6 hembras recolectadas de los mataderos locales. Se tomaron en total 41 medidas diferentes morfológicamente. Los huesos craneales y faciales fueron los componentes principales del cráneo con un total de 32 huesos. Se encontraron tres huesos craneales individuales y cuatro pares con un total de 11 huesos. Encontramos solo un hueso facial individual, los otros 22 eran pares de huesos faciales. Los huesos craneales comprendidos en el estudio fueron: occipital, parietal, interparietal, esfenoides, etmoides, frontal y temporal. Los huesos faciales estudiados fueron: maxilar, premaxilar (incisivo), palatino, pterigoideo, nasal, lagrimal, cigomático, vómer, conchas, mandíbula e hioides. Las mediciones mostraron que el cráneo de la cabra era alargado y dolicocefálico $(47,82 \pm 0,05)$. La longitud y el ancho del cráneo fueron $19,28 \pm 0,03 \mathrm{~cm}$ y 9,22 $\pm 0,04 \mathrm{~cm}$, respectivamente. Había dos forámenes supraorbitales a ambos lados del hueso frontal. La tuberosidad facial prominente se encontraba dorsalmente en el tercer diente premolar superior. El foramen infraorbitario único se localizó dorsalmente a la unión del primer y segundo dientes premolares superiores en el hueso maxilar. Las órbitas eran redondas y completas y situadas en un plano oblicuo frontolateral. En conclusión, los resultados de este estudio motivarán y ayudarán a otros estudios comparativos con otros animales domesticados o en la práctica clínica veterinaria e incluso en zooarqueología.

PALABRAS CLAVE: Cabra; Cráneo; Morfométrico; Índice; Craneal; Facial. 


\section{REFERENCES}

Brünner, H.; Lugon-Moulin, N.; Balloux, F.; Fumagalli, L. \& Hausser, J. A taxonomical re-evaluation of the Valais chromosome race of the common shrew Sorex araneus (Insectivora: Soricidae). Acta Theriol., 47:245-75, 2002.

Choudhary, O. P. \& Singh, I. Applied anatomy of the maxillofacial and mandibular regions of the Indian blackbuck (Antilope cervicapra). $J$. Anim. Res., 5(3):497-500, 2015a.

Choudhary, O. P. \& Singh, I. Morphological and radiographic studies on the skull of Indian blackbuck (Antilope cervicapra). Int. J. Morphol., 34(2):775-83, 2016.

Choudhary, O. P. \& Singh, I. Morphometrical studies on the skull of Indian blackbuck (Antelope cervicapra). Int. J. Morphol., 33(3).868-76, 2015 b.

Choudhary, O. P.; Kalita, P. C.; Doley, P. J. \& Kalita, A. Applied anatomy of the head region of the Indian wild pig (Sus scrofa) and its clinical value during regional anesthesia. J. Anim. Res., 7(2):339-44, 2017.

Choudhary, O. P.; Kalita, P. C.; Doley, P. J.; Kalita, A. \& Arya, R. S. Morphological studies on the cranial bones of Mizoram goats. Indian J. Small Rumin., 25(1):128-30, 2019b.

Choudhary, O. P.; Kalita, P. C.; Kalita, A. \& Doley, P. J. Applied anatomy of the maxillofacial and mandibular regions of the dromedary camel (Camelus dromedarius). J. Camel Pract. Res., 23(1):127-31, 2016.

Choudhary, O. P.; Kalita, P. C.; Konwar, B.; Doley, P. J.; Kalita, G. \& Kalita, A. Morphological and applied anatomical studies on the head region of local Mizo pig (Zovawk) of Mizoram. Int. J. Morphol., 37(1):196204, 2019a.

Choudhary, O. P.; Mathur, R.; Joshi, S.; Beniwal, G. \& Dangi, A. Gross and biometrical studies on carpals of chital (Axis axis). Vet. Pract., 14(1):36-9, 2013a.

Choudhary, O. P.; Mathur, R.; Joshi, S.; Beniwal, G. \& Dangi, A. Gross and biometrical studies on scapula of Chital (Axis axis). Vet. Pract., 14(2):224-7, $2013 \mathrm{~b}$.

Choudhary, O. P.; Singh, I.; Bharti, S. K.; Khan, I. M.; Mohd, K. I.; Sathapathy, S. \& Mrigesh, M. Gross and morphometrical studies on mandible of blackbuck (Antelope cervicapra). Int. J. Morphol., 33(2):428-32, 2015.

Evans, K. E. \& McGreevy, P. D. Conformation of the equine skull: A morphometric study. Anat. Histol. Embryol., 35(4):221-7, 2006.

Getty, R. Sisson and Grossman's: The Anatomy of the Domestic Animals. Vol. 1. $5^{\text {th }}$ ed. Philadelphia, W. B. Saunders Co., 1975.

Goodarzi, N. \& Hoseini, T. S. Morphologic and osteometric analysis of the skull of Markhoz goat (Iranian angora). Vet. Med. Int., 2014 :972682, 2014.

Joshi, H. Gross Anatomical Studies of the Skull of Indian T iger (Panthera tigris). M. V. Sc. Thesis. Bikaner, Rajasthan Agricultural University, 2004.

Kalita, P. C.; Singh, T. S.; Choudhary, O. P.; Debroy, S.; Kalita, A. \& Doley, P. J. Morphological and applied anatomical studies on the head region of Malayan sun bear (Helarctos malayanus). J. Anim. Res., 9(5):753-8, 2019.

Karimi, I.; Onar, V.; Pazvant, G.; Hadipour, M. \& Mazaher, Y. The cranial morphometric and morphologic characteristics of Mehraban sheep in western Iran. Glob. Vet., 6(2):111-7, 2011.

Kataba, A.; Mwaanga, E. S.; Simukoko, H. \& Parés, C. P. M. Clinical anatomy of the head region of Gwembe valley dwarf goat in Zambia. Int. J. Vet. Sci., 3(3):142-6, 2014.

Kumawat, R.; Mathur, R.; Joshi, S. \& Choudhary, O. P. Gross studies on cranial bones of chital (Axis axis). Indian J. Vet. Anat., 26(1):54-5, 2014.

Künzel, W.; Breit, S. \& Oppel, M. Morphometric investigations of breedspecific features in feline skulls and considerations on their functional implications. Anat. Histol. Embryol., 32(4):218-23, 2003.

McGreevy, P.; Grassi, T. D. \& Harman, A. M. A strong correlation exists between the distribution of retinal ganglion cells and nose length in the Dog. Brain Behav. Evol., 63(1):13-22, 2004.
Miller, M. E.; Christensen, G. C. \& Evans, H. E. Anatomy of the Dog Philadelphia, W. B. Saunder's Company, 1964.

Monfared, A. L. Applied anatomy of the head regions of the one-humped camel (Camelus dromedarius) and its clinical implications during regional anesthesia. Glob. Vet., 10(3):322-6, 2013b.

Monfared, A. L. Gross anatomical measurements of the head region of the Iranian native cattle (Bos taurus) and their clinical value for regional anesthesia. Glob. Vet., 10(2):219-22, 2013 a.

Olopade, J. O. \& Onwuka, S. K. A review of the craniofacial and neurometric anatomy of the goat. Trop. Vet., 27(4):1-19, 2009b.

Olopade, J. O. \& Onwuka, S. K. Morphometric analysis of the skull of the Sahel goat breed: basic and clinical anatomy. Ital. J. Anat. Embryol., 114(4):167-78, 2009a.

Olopade, J. O. \& Onwuka, S. K. Morphometric studies of the cranio-facial region of the West African dwarf goat in Nigeria. Int. J. Morphol., 22(2):145-8, 2004.

Olopade, J. O. \& Onwuka, S. K. Osteometric studies of the skull of red sokoto (Maradi) goats (Capra hircus): implications for regional anaesthesia of the head. Int. J. Morphol., 25(2):407-10, 2007.

Olopade, J. O. \& Onwuka, S. K. Some aspects of the clinical anatomy of the mandibular and maxillofacial regions of the West African dwarf goat in Nigeria. Int. J. Morphol., 23(1):33-6, 2005.

Pares, I.; Casanova, P. M.; Kamal, S. \& Jordana, J. On biometrical aspects of the cephalic anatomy of Xisqueta sheep (Catalunya, Spain). Int. J. Morphol., 28(2):347-51, 2010.

Raghavan, D. Anatomy of Ox. New Delhi, Indian Council of Agricultural Research, 1964

Sarma, K. Morphological and craniometrical studies on the skull of Kagani goat (Capra hircus) of Jammu Region. Int. J. Morphol., 24(3):449-55, 2006.

Sisson, S. Ruminant Osteology. In: Getty, R. (Ed.). Sisson and Gpssman's: Anatomy of the DomesticAnimals. $5^{\text {th }}$ ed. Philadelphia, W. B. Sounder's Co., 1964.

Snedecor, G. W. \& Cochran, W. G. Statistical Methods. $8^{\text {th }}$ ed. Ames, Iowa State University Press, 1994.

Sundaram, V.; Dharani, P.; Gnanadevi, R. \& Kavya, R. Studies on clinical anatomy of the maxillofacial and mandibular regions of the Madras red sheep (Ovis aries) in India. Folia Morphol. (Warsz.), 78(2):38993, 2019

Uddin, M. M.; Ahmed, S. S. U.; Islam, K. N. \& Islam, M. M. Clinical anatomy of the head region of the black Bengal goat in Bangladesh. Int. J. Morphol., 27(4):1269-73, 2009.

Zhu, L.; Shi, X. D.; Wang, J. J. \& Chen, J. G. A morphometric study on the skull of donkey (Equus asinus). Int. J. Morphol., 32(4):1306-10, 2014.

Corresponding author:

Dr. O.P. Choudhary

Assistant Professor

Department of Veterinary Anatomy and Histology

College of Veterinary Sciences and Animal Husbandry

Central Agricultural University (I)

Selesih, Aizawl-796 015

Mizoram

INDIA

Email: dr.om.choudhary@gmail.com dr_om_choudhary@yahoo.co.in

Received: 10-04-2020

Accepted: 07-05-2020 